\title{
Coping Well
}

\author{
Mary V. Seeman
}

Published online: 21 June 2020

(C) Springer Nature India Private Limited 2020

My work is with individuals who suffer from serious mental illness, mainly schizophrenia, and also severe forms of all mental illnesses. At the beginning of the confinement, I was concerned that patients would not be able to access doctors and case managers, that they would not be able to get refills of needed medications, that depot antipsychotics and clozapine blood draws would not be possible for them to obtain. I was also worried about practical issues such as spread of the virus among the homeless in shelters and in boarding homes. I didn't know whether very ill patients could be sufficiently informed as to what to do or not to do during the pandemic and whether separation from their family and care providers would drastically undermine their well-being. Another concern was that, overwhelmed with fright, they would flock to Emergency departments in hospitals, places that were already overrun with COVID-19 patients.

As it turned out, none of my worries were justified. Most patients took everything in stride. This has been seen before during disasters, that very ill patients paradoxically improve, perhaps because they are no longer "odd man out," that others are as frightened and as confused as they are. Disasters are great levelers. Although results of studies do not always agree, most of the literature suggests that individuals with a history of reacting badly to stress relapse during trying times, but that those with serious mental illnesses such as schizophrenia, do not.

In general, I found that mental health services also stepped up to the challenge and made certain that services to the most incapacitated were not interrupted. Creative ways were found to reach out to everyone via mobile phone, to convey needed guidance, to hold brief face to face appropriately distanced and masked meetings in sites that stayed open (parks, pharmacies), to maintain channels of communication.

Patients who always prefer to stay home and not socialize found that, now, everyone was following their example. Not shaking hands, not getting close to people, ordering food in, these activities, while new to the general population, were habitual to many individuals with mental illness. For those with employment, the requirement to work from home was welcomed. For those who perceived family visits as burdens, the sanctioned freedom to stay away was also welcomed. Mobile phones have been a much appreciated lifeline throughout [1].

I have been proud of both patients and care providers during this global crisis. 


\section{Reference}

1. Torous J, Keshavan M. COVID-19, mobile health and serious mental illness. Schizophr Res. 2020. https://doi.org/10.1016/ j.schres.2020.04.013.
Publisher's Note Springer Nature remains neutral with regard to jurisdictional claims in published maps and institutional affiliations. 